\title{
Lack of trust hampers hunt for weapons
}

\section{Declan Butler}

Confusion over how the US-led occupying powers will treat Iraqi scientists is hindering the search for weapons of mass destruction in the country, according to a growing number of weapons experts. Until the uncertainty ends, say observers, scientists who could hand over valuable information may be tempted to hide or flee to rogue nations.

The arrest of prominent Iraqi scientists, such as Huda Salih Mahdi Ammash, suspected of developing biological weapons, and Rihab Taha, a senior figure in the country's germwarfare programme, have recently made the headlines. Yet evidence of Iraq's alleged programmes for biological, chemical or nuclear weapons remains elusive, and some observers suggest that the coalition's treatment of Iraqi scientists may be partly to blame.

US radio broadcasts in Iraq have asked scientists to step forward, promising that they "will be treated with respect and dignity". But David Albright, president of the Washingtonbased Institute for Science and International Security and a former nuclear-weapons inspector in Iraq, says that he is in daily contact with Iraqi scientists who fear being taken prisoner by US forces, retaliation by Saddam loyalists, or kidnap and ransom to coalition authorities. Albright believes that all three are happening.

Concern that they may be treated as criminals removes scientists' incentive to cooperate, says Ibrahim al-Marashi, a research associate at the Center for Nonproliferation Studies in Monterey, California. Even those in custody are unlikely to cooperate until they receive assurances that they will not be prosecuted for war crimes, adds Jonathan Tucker, a weapons expert at the US Institute of Peace in Washington.

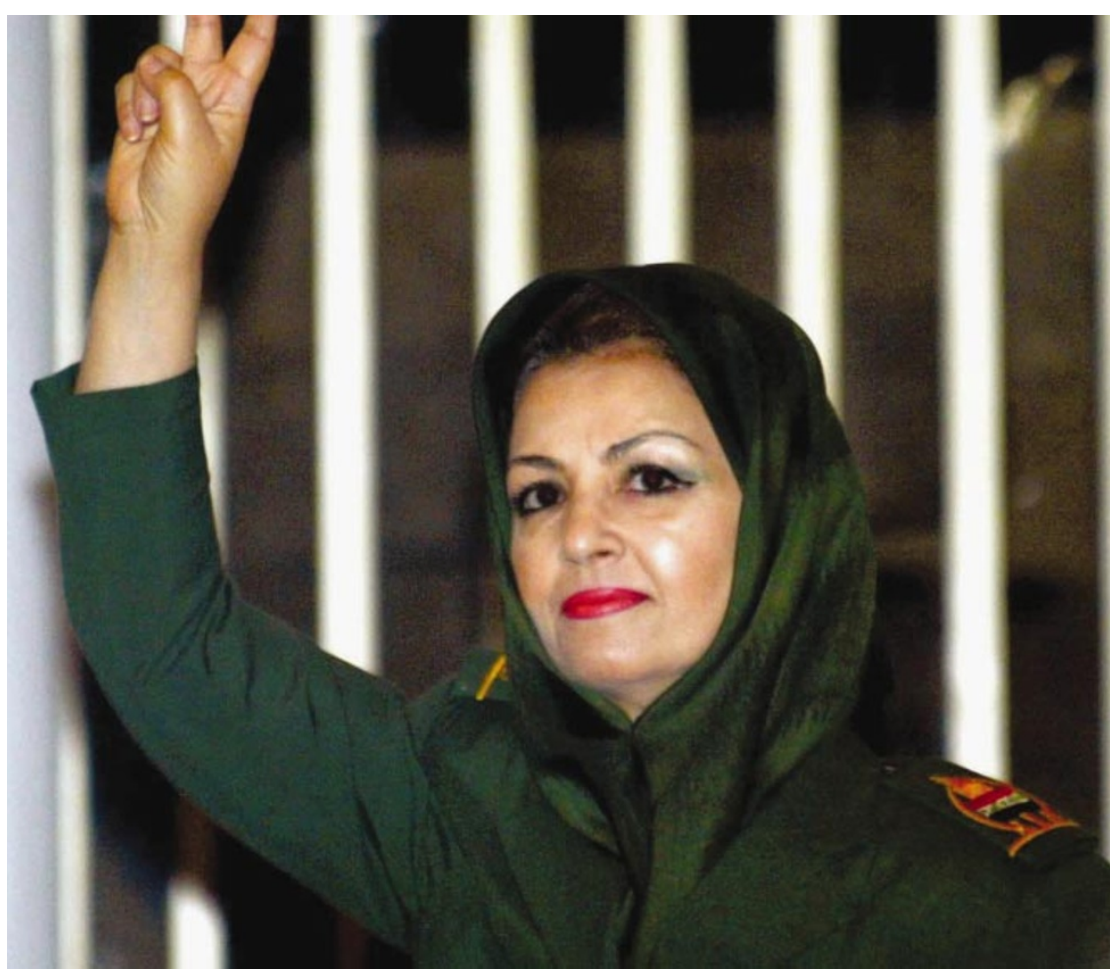

Huda Salih Mahdi Ammash is under arrest, but should rank-and-file Iraqi scientists face the same fate?

Officials at the United Nations Monitoring, Verification and Inspection Commission (UNMOVIC), which the United States has not yet allowed back into Iraq, say that the cooperation of Iraqi scientists is crucial. Without their help, say commission staff, it will difficult to gain an overview of what weapons Iraq might have produced, and in what quantity.

Others experts add that Iraqi scientists will be able to shed light on crucial issues, such as might instead be exacerbating the disease (see Nature 423, 4; 2003). She warned that dexamethasone, an anti-inflammatory corticosteroid, can actually worsen a coronavirus infection in cows and prolong the period of time for which they release virus (H. Tsunemitsu, D. R. Smith and L. J. Saif Arch. Virol. 144, 167-175; 1999).

Saif also cautioned that researchers have had limited success in producing vaccines against animal coronaviruses. Several studies have shown that experimental vaccines against feline infectious peritonitis virus (FIPV), for example, can aggravate the infection through a phenomenon called antibody-dependent enhancement. Antibodies produced in response to vaccination with FIPV proteins bind to the virus and boost its uptake by immune cells called macrophages. Other viruses are destroyed when engulfed by macrophages, but in this case the FIPV multiplies inside the cells.

This suggests that one possible strategy to fight SARS - collecting and injecting antibodies from recovering patients into new patients - might similarly inflame the disease. Pharmaceutical-industry representatives at the meeting reiterated that the hope of a quick drug or vaccine for SARS is slim. A new antiviral drug would take a minimum of four to five years to reach the shelf, they said, a vaccine closer to six.

www.nyas.columbia.edu the fate of Iraq's dual-use materials - substances that could be used to create weapons but which could also have peaceful applications. And some observers note that, in the past, weapons programmes have remained hidden until being revealed by scientists.

Tucker argues that weapons scientists who were not key figures in Saddam's regime should be given an amnesty and incentives to cooperate, to discourage them from fleeing or selling their talents elsewhere. He recommends that a centre be set up in Baghdad to offer weapons scientists stable employment, along the lines of the International Science and Technology Center in Moscow, an intergovernmental organization established in 1992 to divert the talents of Soviet weapons scientists to peaceful ends.

But others question how much information Iraqi scientists will be able to supply. "Very few people were probably in the know - only those closest to Saddam or the 'simpletons' who did the actual concealment work," says Ephraim Asculai of the Jaffee Center for Strategic Studies at Tel Aviv University in Israel.

The current coalition weapons inspectors are due to be replaced in the coming weeks by the Iraq Survey Group, a 2,000-strong Pentagon-led body that will investigate everything from weapons and potential war crimes to terrorist connections. The coalition has not yet responded to requests to allow inspectors from UNMOVIC or the International Atomic Energy Agency to return to Iraq. 